Article

\title{
Study on the Physical and Leakage Current Characteristics of an Optimized High-k/InAlAs MOS Capacitor with a $\mathrm{HfO}_{2}-\mathrm{Al}_{2} \mathrm{O}_{3}$ Laminated Dielectric
}

\author{
He Guan * and Chengyu Jiang \\ School of Electronics and Information, Northwestern Polytechnical University (NPU), Xi'an 710072, China; \\ 2013301856@mail.nwpu.edu.cn \\ * Correspondence: he.guan@nwpu.edu.cn
}

Received: 26 October 2018; Accepted: 20 November 2018; Published: 22 November 2018

\begin{abstract}
High-k/n-InAlAs MOS capacitors are popular for the isolated gate of InAs/AlSb and InAlAs/InGaAs high-electron mobility transistors. In this study, a new kind of high- $\mathrm{k} / \mathrm{n}-\mathrm{InAlAs}$ MOS-capacitor with a $\mathrm{HfO}_{2}-\mathrm{Al}_{2} \mathrm{O}_{3}$ laminated dielectric was successfully fabricated using an optimized process. Compared with the traditional $\mathrm{HfO}_{2} / \mathrm{n}$-InAlAs MOS capacitor, the new device has a larger equivalent oxide thickness. Two devices, with a $\mathrm{HfO}_{2}(8 \mathrm{~nm})-\mathrm{Al}_{2} \mathrm{O}_{3}(4 \mathrm{~nm})$ laminated dielectric and a $\mathrm{HfO}_{2}(4 \mathrm{~nm})-\mathrm{Al}_{2} \mathrm{O}_{3}(8 \mathrm{~nm})$ laminated dielectric, respectively, were studied in comparison to analyze the effect of the thickness ratios of $\mathrm{HfO}_{2}$ and $\mathrm{Al}_{2} \mathrm{O}_{3}$ on the performance of the devices. It was found that the device with a $\mathrm{HfO}_{2}(4 \mathrm{~nm})-\mathrm{Al}_{2} \mathrm{O}_{3}(8 \mathrm{~nm})$ laminated dielectric showed a lower effective density of oxide charges, and an evidently higher conduction band offset, making its leakage current achieve a significantly low value below $10^{-7} \mathrm{~A} / \mathrm{cm}^{2}$ under a bias voltage from -3 to $2 \mathrm{~V}$. It was demonstrated that the $\mathrm{HfO}_{2}-\mathrm{Al}_{2} \mathrm{O}_{3}$ laminated dielectric with a $\mathrm{HfO}_{2}$ thickness of $4 \mathrm{~nm}$ and an $\mathrm{Al}_{2} \mathrm{O}_{3}$ thickness of $8 \mathrm{~nm}$ improves the performance of the high- $\mathrm{k}$ dielectric on InAlAs, which is advantageous for further applications.
\end{abstract}

Keywords: high- $\mathrm{k} / \mathrm{InAlAs}$ MOS-capacitor; $\mathrm{HfO}_{2}-\mathrm{Al}_{2} \mathrm{O}_{3}$ laminated dielectric; leakage current; $C-V$ characteristics

\section{Introduction}

Owing to the requirements of high speed, low dissipation, and low noise for modern integrated circuits, InAs/AlSb and InAlAs/InGaAs high-electron mobility transistors (HEMTs) are receiving great attention as new III-V compound devices because of their high electron mobility and electron saturation drift speed [1-4]. Because of its good compatibility with AlSb, InAs, and InGaAs, InAlAs is one of the most promising materials for the protection layer of InAs/AlSb and InAlAs/InGaAs HEMTs to enhance the carrier density in the channel [1,3]. Depositing a high-k dielectric film on InAlAs as a MOS capacitor can effectively suppress the leakage current [5-9]. However, the lack of reasonable high-k dielectrics is still a major problem that limits the performance of the isolated gate. $\mathrm{HfO}_{2}$ is the main candidate for the high-k dielectric because of its high dielectric constant [5,7], but its direct deposition on InAlAs limits its performance owing to the poor lattice match with InAlAs [8]. Therefore, a thin $\mathrm{Al}_{2} \mathrm{O}_{3}$ film inserted between InAlAs and $\mathrm{HfO}_{2}$ as a buffer layer has been proposed [8]. This structure can increase the quality of the MOS capacitor by providing a better match with InAlAs. Reference [8] initially reported the electrical and interfacial characteristics of a $\mathrm{HfO}_{2}-\mathrm{Al}_{2} \mathrm{O}_{3} / \mathrm{n}$-InAlAs MOS-capacitor. However, in [8], the impact of the thickness of $\mathrm{HfO}_{2}$ and $\mathrm{Al}_{2} \mathrm{O}_{3}$ on the performance of the device was not investigated, and the leakage current performance, which is considered as the most important electrical characteristic of the MOS-capacitor was not mentioned either. In order to 
optimize the fabrication process and improve the performance of the high- $\mathrm{k} / \mathrm{InAlAs}$ MOS-capacitor with an $\mathrm{HfO}_{2}-\mathrm{Al}_{2} \mathrm{O}_{3}$ laminated dielectric, a new kind of $\mathrm{HfO}_{2}-\mathrm{Al}_{2} \mathrm{O}_{3} / \mathrm{n}$-InAlAs MOS-capacitor was manufactured in this study, and its optimized fabrication process was discussed in detail. Two samples with $\mathrm{HfO}_{2}(8 \mathrm{~nm}) / \mathrm{Al}_{2} \mathrm{O}_{3}(4 \mathrm{~nm})$ and $\mathrm{HfO}_{2}(4 \mathrm{~nm}) / \mathrm{Al}_{2} \mathrm{O}_{3}(8 \mathrm{~nm})$ were designed and prepared to investigate the effect of the different thickness ratios of $\mathrm{HfO}_{2}$ and $\mathrm{Al}_{2} \mathrm{O}_{3}$. Devices were tested by atomic force microscope (AFM), Focused Ion beam (FIB), scanning electron microscope (SEM), and X-ray photoelectron spectroscopy (XPS) to describe the physical characteristics. Based on the capacitance $(C)$-voltage $(V)$ and current $(I)-V$ test results, their physical characteristics were analyzed and their electrical characteristics, including the leakage current, were investigated in detail.

\section{Materials and Methods}

The structure diagram of the MOS capacitor is shown in Figure 1. To match with InAlAs and achieve better performance, InP was selected as the substrate rather than GaAs, which were frequently used in other studies [7-9]. InP is semi-insulating and a 350- $\mu \mathrm{m}$-thick substrate was used. To decrease the lattice mismatch with InAlAs, a 200-nm-thick InP buffer layer was grown on the InP substrate by $\mathrm{MBE}$ at $470{ }^{\circ} \mathrm{C}$. A 500 -nm-thick Si-doped $\mathrm{In}_{0.5} \mathrm{Al}_{0.5}$ As layer with a doping concentration of $1 \times 10^{17} \mathrm{~cm}^{-3}$ was deposited on the InP buffer layer. The high-k dielectric was then deposited by atomic layer deposition (ALD) [10-13]. The details of the ALD process to produce the $\mathrm{HfO}_{2}-\mathrm{Al}_{2} \mathrm{O}_{3}$ laminated dielectric are given in Table 1. We controlled the ALD process circle to manufacture different dielectric thicknesses. A post-deposition annealing (PDA) process was applied to increase the quality of the oxide-semiconductor interface [14-17]. The process involved heating the film from ambient temperature to $380^{\circ} \mathrm{C}$ in $\mathrm{N}_{2}$ over $15 \mathrm{~s}$, annealing for $60 \mathrm{~s}$, and then cooling to ambient temperature over $300 \mathrm{~s}$ [6,7]. Finally, a Ti $(20 \mathrm{~nm}) / \mathrm{Pt}(20 \mathrm{~nm}) / \mathrm{Au}(200 \mathrm{~nm})$ metal structure was grown as the electrode by the magnetron sputtering technique. We grew two electrodes with different areas. The area of the small one is $150 \mu \mathrm{m} \times 150 \mu \mathrm{m}$ (marked as $C_{1}$ in Figure 1), and the area of the large one is $1500 \times 1500 \mu \mathrm{m}^{2}$ (marked as $C_{2}$ in Figure 1). When a voltage is applied between the two electrodes, $C_{1}$ is connected in series with $C_{2}$. Because the area of $C_{2}$ is 100 times larger than the area of $C_{1}$, the influence of $C_{2}$ on the total capacitance can be neglected, and the measured capacitance can be approximately equal to the value of $C_{1}$. The electrodes that grow on top of the oxide layer can avoid the pollution caused by the back contact process used in [8] (e.g., the metal directly deposited on the surface of InAlAs).

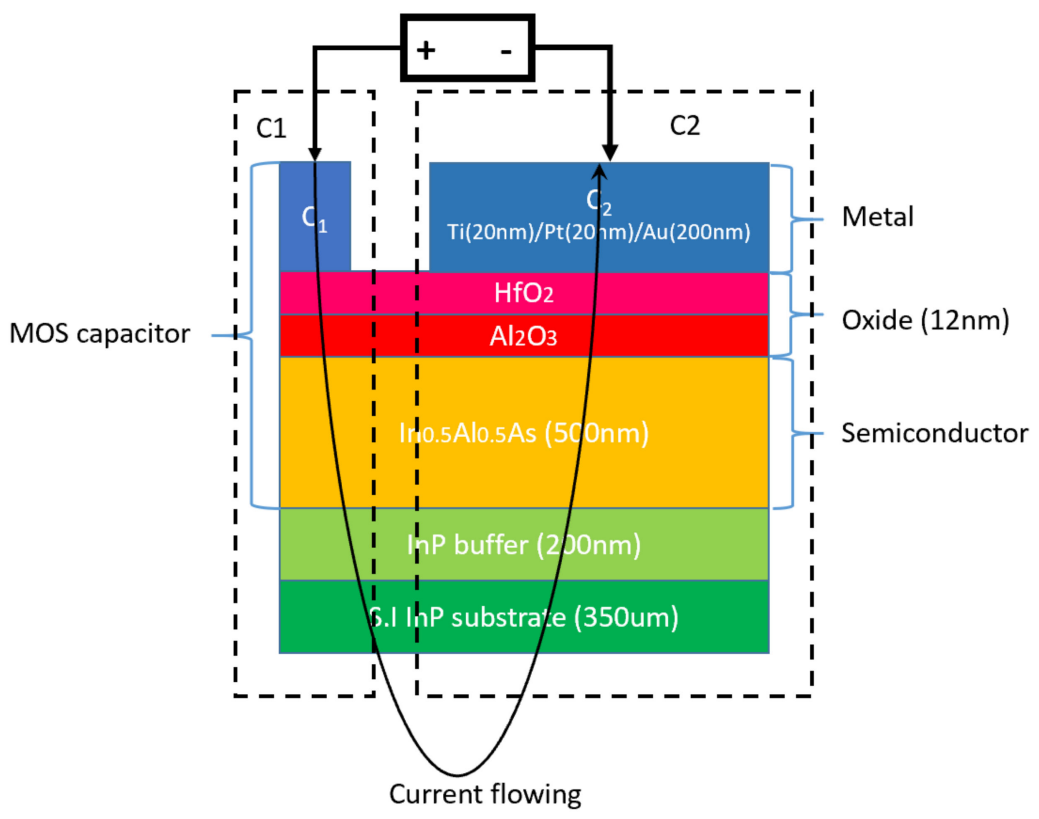

Figure 1. Structure diagram of the MOS capacitor. 
Table 1. ALD process to prepare the $\mathrm{HfO}_{2}-\mathrm{Al}_{2} \mathrm{O}_{3}$ dielectric.

\begin{tabular}{cccccc}
\hline Dielectric & Precursor & Pulse Time (s) & $\begin{array}{c}\text { Deposition } \\
\text { Temperature }\left({ }^{\circ} \mathrm{C}\right)\end{array}$ & $\begin{array}{c}\text { Pressure } \\
(\mathbf{m b a r})\end{array}$ & $\begin{array}{c}\text { Deposition } \\
\text { Speed (nm/s) }\end{array}$ \\
\hline $\mathrm{Al}_{2} \mathrm{O}_{3}$ & $\begin{array}{c}\mathrm{TMT}+\mathrm{N}_{2}+ \\
\mathrm{H}_{2} \mathrm{O}+\mathrm{N}_{2}\end{array}$ & $0.5+2+0.5+1$ & 245 & 2.3 & 0.1 \\
$\mathrm{HfO}_{2}$ & $\begin{array}{c}\mathrm{TEMAH}+\mathrm{N}_{2}+ \\
\mathrm{H}_{2} \mathrm{O}+\mathrm{N}_{2}\end{array}$ & $1+2+1+2$ & 245 & 2.3 & 0.1 \\
\hline
\end{tabular}

A simple $\mathrm{HfO}_{2} / \mathrm{n}$-InAlAs MOS capacitor with an oxide thickness of $12 \mathrm{~nm}$ and two $\mathrm{HfO}_{2}-\mathrm{Al}_{2} \mathrm{O}_{3} / \mathrm{n}$-InAlAs MOS capacitors with $\mathrm{HfO}_{2}(8 \mathrm{~nm}) / \mathrm{Al}_{2} \mathrm{O}_{3}(4 \mathrm{~nm})$ and $\mathrm{HfO}_{2}(4 \mathrm{~nm}) / \mathrm{Al}_{2} \mathrm{O}_{3}$ $(8 \mathrm{~nm})$ laminated dielectrics were fabricated. These three samples were designed to have the same physical oxide thickness of $12 \mathrm{~nm}$ for convenient comparison. The surface roughness RMS (root-mean-square) values of the three samples which are taken from the AFM test are observed as small, around $0.5 \mathrm{~nm}$. The $5 \mu \mathrm{m} \times 5 \mu \mathrm{m}$ AFM graph of the $\mathrm{HfO}_{2}(4 \mathrm{~nm}) / \mathrm{Al}_{2} \mathrm{O}_{3}(8 \mathrm{~nm}) \mathrm{MOS}$ capacitor is show in Figure 2a. The FIB-SEM image of the across-section of the $\mathrm{HfO}_{2}(4 \mathrm{~nm}) / \mathrm{Al}_{2} \mathrm{O}_{3}(8 \mathrm{~nm}) \mathrm{MOS}$ capacitor is shown in Figure $2 \mathrm{~b}$. These indicate a compactable and homogeneous device structure.

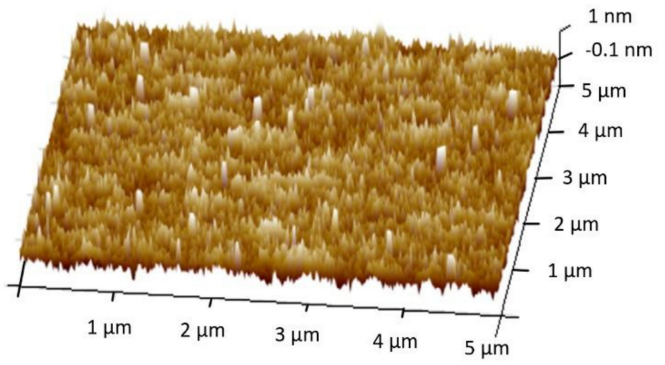

(a)

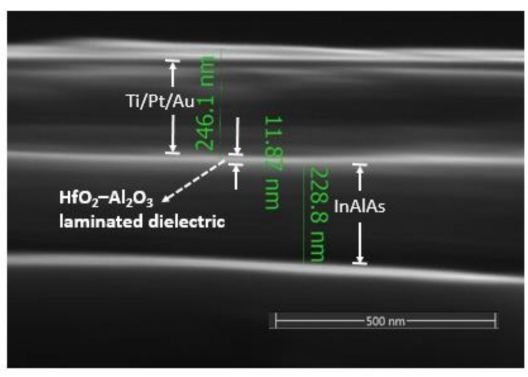

(b)

Figure 2. (a) AFM graph of the $\mathrm{HfO}_{2}(4 \mathrm{~nm}) / \mathrm{Al}_{2} \mathrm{O}_{3}(8 \mathrm{~nm}) \mathrm{MOS}$ capacitor; (b) FIB-SEM image of the across-section of the $\mathrm{HfO}_{2}(4 \mathrm{~nm}) / \mathrm{Al}_{2} \mathrm{O}_{3}(8 \mathrm{~nm}) \mathrm{MOS}$ capacitor.

\section{Results and Discussions}

The accumulated capacitances of the MOS-capacitors $C_{\mathrm{OX}}$ were measured by the high-frequency capacitance method at $1 \mathrm{MHz}$, and the results are shown in Figure 3. The $\mathrm{HfO}_{2} / \mathrm{InAlAs} \mathrm{MOS}$ capacitor has a highest $C_{\mathrm{OX}}$ of $0.68 \mu \mathrm{F} / \mathrm{cm}^{2}$, while the $C_{\mathrm{OX}}$ is lower with an inserted $\mathrm{Al}_{2} \mathrm{O}_{3}$ thin film. The $C_{\mathrm{OX}}$ value decreases with increasing thickness of the inserted $\mathrm{Al}_{2} \mathrm{O}_{3}$ layer. The highest $C_{\mathrm{OX}}$ values of the $\mathrm{HfO}_{2}$ $(8 \mathrm{~nm}) / \mathrm{Al}_{2} \mathrm{O}_{3}(4 \mathrm{~nm}) / \mathrm{InAlAs}$ and $\mathrm{HfO}_{2}(4 \mathrm{~nm}) / \mathrm{Al}_{2} \mathrm{O}_{3}(8 \mathrm{~nm}) / \mathrm{InAlAs}$ MOS capacitors are 0.517 and $0.355 \mu \mathrm{F} / \mathrm{cm}^{2}$, respectively. It is noted that $C_{O X}$ shows a decrease as the MOS capacitor is driven further into accumulation. This is induced by the obvious leakage current under the high voltage bias condition. In addition, a low $C-V$ hysteresis is observed for the sample with $\mathrm{HfO}_{2}(4 \mathrm{~nm}) / \mathrm{Al}_{2} \mathrm{O}_{3}(8 \mathrm{~nm})$ laminated dielectrics. The reason can be explained by its lowest density of oxide charges that we discuss herein.

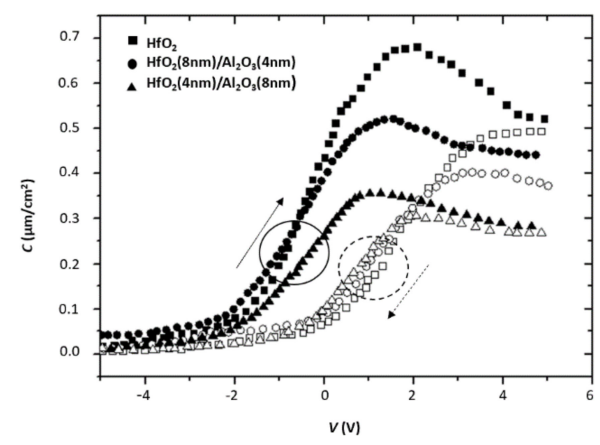

Figure 3. $C-V$ measurements of the MOS capacitors. 
The equivalent oxide thickness (EOT) values of the three samples were determined from the $C-V$ curves $[7,9]$. The results are given in Table 2. Inserting $\mathrm{Al}_{2} \mathrm{O}_{3}$ increases the EOT. When the thickness of $\mathrm{Al}_{2} \mathrm{O}_{3}$ is 4 and $8 \mathrm{~nm}$, the EOT values are 6.68 and $9.73 \mathrm{~nm}$, respectively. Because the electric field intensity $E_{\mathrm{i}}$ is inversely proportional to the EOT for fixed bias voltage $V_{\mathrm{g}}$, the higher EOT indicates that inserting an $\mathrm{Al}_{2} \mathrm{O}_{3}$ film between InAlAs and $\mathrm{HfO}_{2}$ decreases $E_{\mathrm{i}}$ under the same $V_{\mathrm{g}}$, which will help to decrease the leakage current. It is noted that the increased EOT would degrade the gate control ability of the device. The equivalent dielectric constant $\varepsilon_{\mathrm{OX}}$ was calculated according to the $C-V$ test data [18]. The two samples with a $\mathrm{HfO}_{2} / \mathrm{Al}_{2} \mathrm{O}_{3}$ laminated dielectric have lower $\varepsilon_{\mathrm{O}}$ values than the sample with only a $\mathrm{HfO}_{2}$ dielectric, and the $\varepsilon_{\mathrm{OX}}$ value decreases as the thickness of the $\mathrm{Al}_{2} \mathrm{O}_{3}$ film increases. This can be explained by the lower dielectric constant of $\mathrm{Al}_{2} \mathrm{O}_{3}$ than $\mathrm{HfO}_{2}$.

Table 2. Physical and electrical parameters of the $\mathrm{HfO}_{2} / \mathrm{n}$-InAlAs and $\mathrm{HfO}_{2}-\mathrm{Al}_{2} \mathrm{O}_{3} / \mathrm{n}-\mathrm{InAlAs}$ MOS capacitors.

\begin{tabular}{cccc}
\hline Parameter & $\begin{array}{c}\mathbf{H f O}_{2} / \mathbf{n}- \\
\text { InAlAs }\end{array}$ & $\begin{array}{c}\mathbf{H f O}_{\mathbf{2}}(\mathbf{8 n m}) / \mathbf{A l}_{\mathbf{2}} \mathbf{O}_{3} \\
(\mathbf{4 n m}) / \mathbf{n}-\mathbf{I n A l A s}\end{array}$ & $\begin{array}{c}\mathbf{H f O}_{\mathbf{2}}(\mathbf{4 n m}) / \mathbf{A l}_{\mathbf{2}} \mathbf{O}_{3} \\
\mathbf{( 8 n m}) / \mathbf{n}-\mathbf{I n A l A s}\end{array}$ \\
\hline$C_{\mathrm{OX}}\left(\mu \mathrm{F} / \mathrm{cm}^{2}\right)$ & 0.680 & 0.517 & 0.355 \\
$\mathrm{EOT}(\mathrm{nm})$ & 5.08 & 6.68 & 9.73 \\
$\varepsilon_{\mathrm{OX}}$ & 9.22 & 7.01 & 4.81 \\
$C_{\mathrm{FB}}\left(\mu \mathrm{F} / \mathrm{cm}^{2}\right)$ & 0.374 & 0.319 & 0.249 \\
$V_{\mathrm{FB}}(\mathrm{V})$ & -0.31 & -0.44 & -0.23 \\
$N_{\mathrm{eff}}\left(\mathrm{cm}^{-2}\right)$ & $1.83 \times 10^{12}$ & $1.81 \times 10^{12}$ & $0.78 \times 10^{12}$ \\
$\Delta E_{\mathrm{CB}}(\mathrm{eV})$ & 1.120 & 1.179 & 1.563 \\
\hline
\end{tabular}

The effective density of oxide charges $N_{\text {eff }}$, which indicates the quality of the MOS capacitor, and can be estimated from the flat-band capacitance $C_{\mathrm{FB}}$ and flat-band voltage $V_{\mathrm{FB}}[7,19]$. The estimated values for the samples are listed in Table 2. First, we will compare the $N_{\text {eff }}$ values of the samples with a single $\mathrm{HfO}_{2}$ dielectric and a $\mathrm{HfO}_{2}(8 \mathrm{~nm}) / \mathrm{Al}_{2} \mathrm{O}_{3}(4 \mathrm{~nm})$ laminated dielectric. Because $\mathrm{Al}_{2} \mathrm{O}_{3}$ possesses better matching with InAlAs than $\mathrm{HfO}_{2}$, inserting an $\mathrm{Al}_{2} \mathrm{O}_{3}$ film improves the interface quality [8,9], which helps to suppress spreading of the impurities in the dielectric layer. However, another interface is generated between $\mathrm{Al}_{2} \mathrm{O}_{3}$ and $\mathrm{HfO}_{2}$ because of insertion of the $\mathrm{Al}_{2} \mathrm{O}_{3}$ film, leading to generation of additional interface states, which will induce an increase in traps. These competing effects mean that the $N_{\text {eff }}$ values of the two samples are similar. The $N_{\text {eff }}$ values are $0.78 \times 10^{12} \mathrm{~cm}^{-2}$ for the sample with a $\mathrm{HfO}_{2}(4 \mathrm{~nm}) / \mathrm{Al}_{2} \mathrm{O}_{3}(8 \mathrm{~nm})$ laminated dielectric and $1.81 \times 10^{12}$ for the sample with a $\mathrm{HfO}_{2}(8 \mathrm{~nm}) / \mathrm{Al}_{2} \mathrm{O}_{3}(4 \mathrm{~nm})$ laminated dielectric. Thus, $N_{\text {eff }}$ decreases as the thickness of $\mathrm{Al}_{2} \mathrm{O}_{3}$ increases. This reduction can be explained by the better interfacial quality of the sample with a thicker $\mathrm{Al}_{2} \mathrm{O}_{3}$ layer. In addition, the stability of $\mathrm{Al}_{2} \mathrm{O}_{3}$ is higher than $\mathrm{HfO}_{2}$ and the oxygen atoms in $\mathrm{Al}_{2} \mathrm{O}_{3}$ are more difficult to remove by other impurity bonds (e.g., In- and As-) to form In-O and As-O traps, so the sample with a thicker $\mathrm{Al}_{2} \mathrm{O}_{3}$ layer has lower $\mathrm{N}_{\text {eff }}$. For verification, XPS was performed to check the diffusion states of the As and In elements in the oxide layer. The XPS spectra before and after $30 \mathrm{~s}$ etching on the oxide layer are shown in Figure 4 ( $30 \mathrm{~s}$ etching is estimated to reach $6 \mathrm{~nm}$ depth of oxide layer). The XPS spectra is shown in Figure 4. In general, the As $3 d$ and In $3 d$ peaks before etching are lower than those after $30 \mathrm{~s}$ etching because of the blocking action of the high-k dielectric on impurities. Compared with the $\mathrm{Hf}-\mathrm{O}$ bond, the $\mathrm{Al}-\mathrm{O}$ bond shows a stronger blocking effect on diffusion of impurity particles, so the sample with $\mathrm{HfO}_{2}(4 \mathrm{~nm}) / \mathrm{Al}_{2} \mathrm{O}_{3}(8 \mathrm{~nm})$ has a lower concentration of As than the sample with $\mathrm{HfO}_{2}(8 \mathrm{~nm}) / \mathrm{Al}_{2} \mathrm{O}_{3}(4 \mathrm{~nm})$. Although $\mathrm{Al}_{2} \mathrm{O}_{3}$ can block the diffusion of As, the $4 \mathrm{~nm}$ thickness does not perform a good blocking role, indicating that $\mathrm{Al}_{2} \mathrm{O}_{3}$ must have a reasonable thickness for a good blocking effect on impurities. Diffusion of As in the oxide layer is suppressed when the thickness of $\mathrm{Al}_{2} \mathrm{O}_{3}$ is increased to $8 \mathrm{~nm}$, which suppresses the formation of charge traps in the oxide layer and reduces the $N_{\text {eff }}$ value. In addition, the In content before etching is negligible because of the weak diffusion of In in the oxide layer. The lower $N_{\text {eff }}$ is helpful to suppress the hysteresis phenomenon in the $C-V$ curve. This explains the lowest $C-V$ hysteresis for the sample with the $\mathrm{HfO}_{2}(4 \mathrm{~nm}) / \mathrm{Al}_{2} \mathrm{O}_{3}(8 \mathrm{~nm})$ laminated dielectric (Figure 3). 

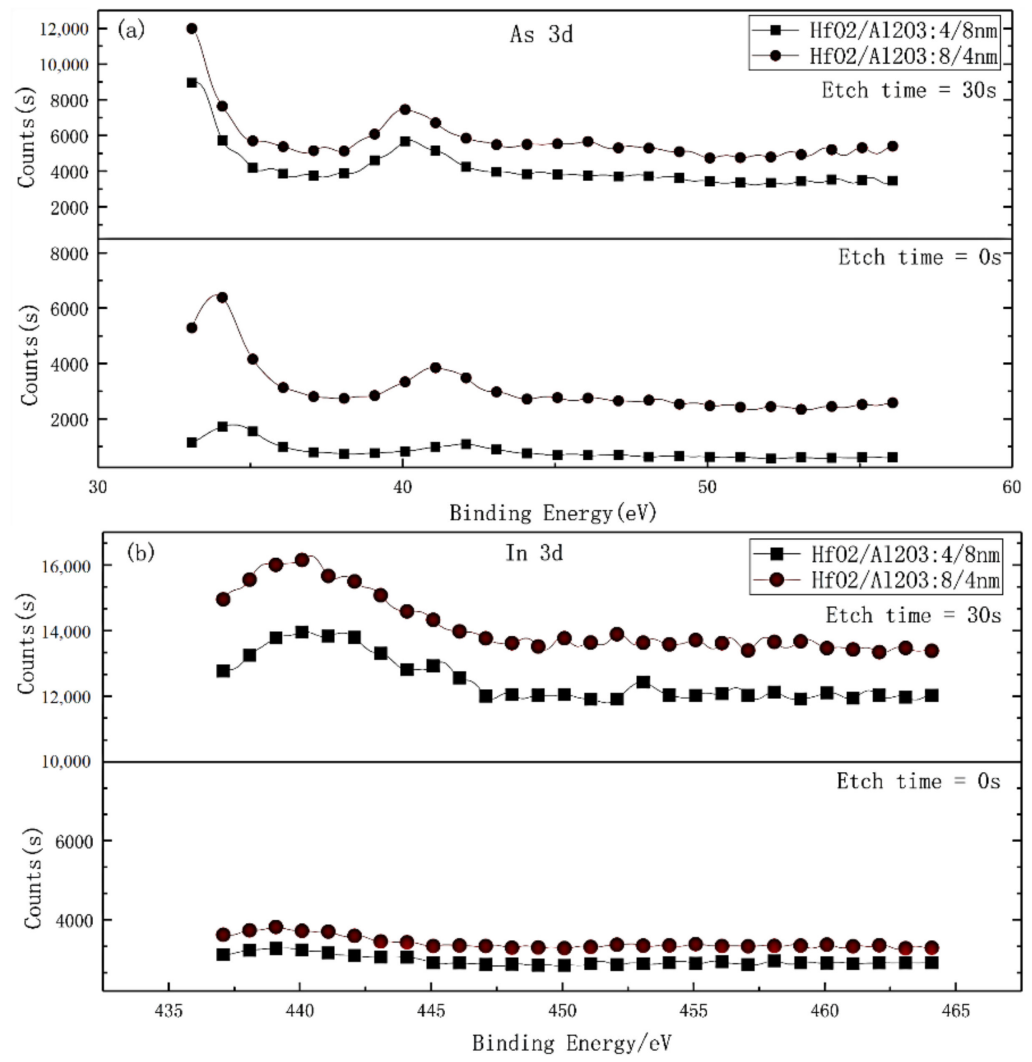

Figure 4. XPS spectra before and after etching for $30 \mathrm{~s}$ : (a) As 3d; (b) In 3d.

The leakage currents of the MOS capacitors are shown in Figure 5. For negative bias voltage, compared with the reported results in [7,9], the leakage current density of the new $\mathrm{HfO}_{2}(4 \mathrm{~nm}) / \mathrm{Al}_{2} \mathrm{O}_{3}(8 \mathrm{~nm}) / \mathrm{n}$-InAlAs MOS capacitor is significantly lower in the $V_{\mathrm{g}}$ range from -3 to $2 \mathrm{~V}$ (below $10^{-7} \mathrm{~A} / \mathrm{cm}^{2}$ ), and it is one order of magnitude lower than that of the $\mathrm{HfO}_{2} / \mathrm{n}$-InAlAs MOS capacitor. One reason is that inserting an $\mathrm{Al}_{2} \mathrm{O}_{3}$ film enhances the match between $\mathrm{HfO}_{2}$ and InAlAs by suppressing the formation of a low- $\mathrm{k}$ interfacial layer. In addition, $\mathrm{Al}_{2} \mathrm{O}_{3}$ has a higher barrier height than $\mathrm{HfO}_{2}$, which makes the $\mathrm{HfO}_{2}-\mathrm{Al}_{2} \mathrm{O}_{3} /$ n-InAlAs MOS capacitor possess less accessibility for carriers to overcome the barrier and form leakage current. Under positive bias voltage, electrons cross the barrier at the high- $\mathrm{k} / \mathrm{InAlAs}$ interface $\left(\varphi_{\mathrm{B}}\right)$ and contribute to the leakage current $[20,21]$. In general, the conduction band offset $\left(\Delta E_{\mathrm{CB}}\right)$ between oxide and the semiconductor layer is used to determine $\varphi_{\mathrm{B}}$ [6]. To further investigate the reason for the barrier effect on the leakage current, $\Delta E_{\mathrm{CB}}$ was calculated by the Krant method [6]. The results are listed in Table 2. It should be noted that the sample with $\mathrm{HfO}_{2}(4 \mathrm{~nm}) / \mathrm{Al}_{2} \mathrm{O}_{3}(8 \mathrm{~nm})$ laminated dielectric shows the highest band offset $\Delta E_{\mathrm{CB}}(1.563 \mathrm{eV})$, which can be explained by its higher barrier height of $\mathrm{Al}_{2} \mathrm{O}_{3}$, so the sample with an 8-nm-thick $\mathrm{Al}_{2} \mathrm{O}_{3}$ film shows significantly lower leakage current. The sample with $\mathrm{HfO}_{2}(8 \mathrm{~nm}) / \mathrm{Al}_{2} \mathrm{O}_{3}(4 \mathrm{~nm})$ laminated dielectric shows a competitive $\Delta E_{\mathrm{CB}}$ value single $(1.179 \mathrm{eV})$ with the sample with $\mathrm{HfO}_{2}$ dielectric $(1.120 \mathrm{eV})$. However, the sample with $\mathrm{HfO}_{2}(8 \mathrm{~nm}) / \mathrm{Al}_{2} \mathrm{O}_{3}(4 \mathrm{~nm})$ laminated dielectric shows a higher leakage current than the sample with single $\mathrm{HfO}_{2}$ dielectric when a positive bias voltage is applied. It can be explained as following: $\mathrm{A} 4 \mathrm{~nm} \mathrm{Al}_{2} \mathrm{O}_{3}$ layer is too thin to suppress the leakage current effectively; meanwhile, the additional states on the $\mathrm{Al}_{2} \mathrm{O}_{3}-\mathrm{HfO}_{2}$ interface degrade the leakage current. Therefore, the sample with $\mathrm{HfO}_{2}(8 \mathrm{~nm}) / \mathrm{Al}_{2} \mathrm{O}_{3}(4 \mathrm{~nm})$ dielectric shows the lowest leakage. The leakage current mechanism of devices is complicated, and will be investigated in detail in our next work. 


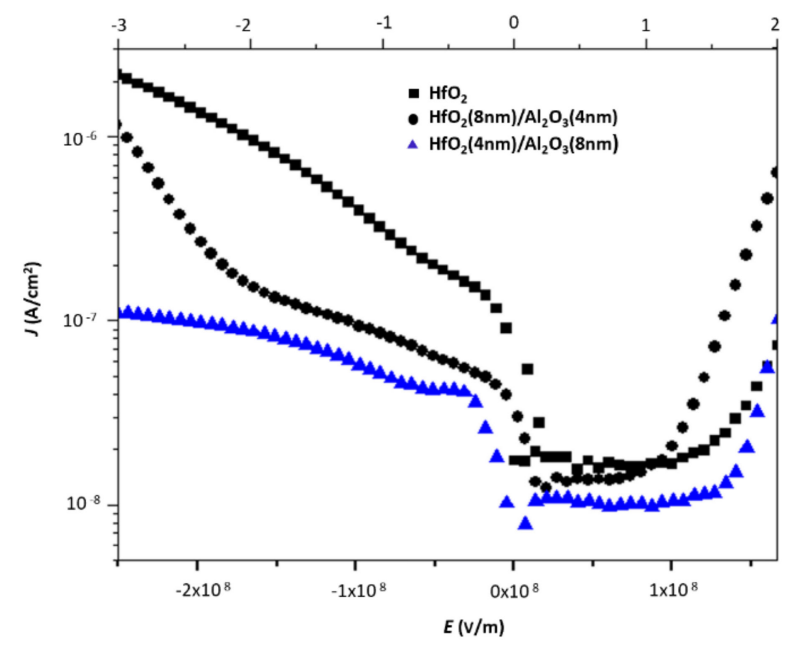

Figure 5. Leakage current density $J_{\text {leakage }}$ measurements under bias voltage from -3 to $2 \mathrm{~V}$ for the three MOS capacitors.

The physical and electrical parameters of the $\mathrm{HfO}_{2} / \mathrm{n}$-InAlAs and $\mathrm{HfO}_{2}-\mathrm{Al}_{2} \mathrm{O}_{3} / \mathrm{n}$-InAlAs MOS capacitors are compared in Table 2.

\section{Conclusions}

In conclusion, compared with the $\mathrm{HfO}_{2} / \mathrm{n}$-InAlAs MOS capacitor, the $\mathrm{HfO}_{2}-\mathrm{Al}_{2} \mathrm{O}_{3} / \mathrm{n}$-InAlAs MOS capacitor has the higher EOT and lower $N_{\text {eff }}$, which help to suppress the leakage current. The $\mathrm{HfO}_{2}-\mathrm{Al}_{2} \mathrm{O}_{3} / \mathrm{n}$-InAlAs MOS capacitor has a high conduction band offset, making its leakage current below $10^{-7} \mathrm{~A} / \mathrm{cm}^{2}$ under bias voltage from -3 to $2 \mathrm{~V}$. Therefore, the $\mathrm{Al}_{2} \mathrm{O}_{3}-\mathrm{HfO}_{2}$ laminated dielectric improves the high-k gate dielectric on InAlAs and suppresses the leakage current. The $\mathrm{HfO}_{2}-\mathrm{Al}_{2} \mathrm{O}_{3} / \mathrm{n}$-InAlAs MOS capacitor with $\mathrm{HfO}_{2}$ thickness of $4 \mathrm{~nm}$ and $\mathrm{Al}_{2} \mathrm{O}_{3}$ thickness of $8 \mathrm{~nm}$ is a good candidate for the isolated gate of InAs/AlSb and InAlAs/InGaAs HEMTs.

Author Contributions: Software, C.J.; Formal Analysis, H.G.; Investigation, H.G.; Writing-Original Draft Preparation, H.G.; Writing-Review \& Editing, C.J.; Project Administration, H.G.

Funding: The project was funded by the National Science Foundation of Shaanxi Province, China (No. 2018JQ6069) and Natural Science Foundation of Shaanxi Province (No. 2017JQ6051).

Conflicts of Interest: The authors declare no conflict of interest.

\section{References}

1. Moschetti, G.; Wadefalk, N.; Nilsson, P.A.; Roelens, Y.; Noudeviwa, A.; Desplanque, L.; Wallart, X.; Danneville, F.; Dambrine, G.; Bollaert, S. InAs / AlSb HEMTs for cryogenic lnAs at ultra-low power dissipation. Solid State Electron. 2011, 64, 47-53. [CrossRef]

2. Moschetti, G.; Nilsson, P.A.; Wadefalk, N.; Malmkvist, M.; Lefebvre, E.; Grahn, J.; Roelens, Y.; Noudeviwa, A.; Olivier, A.; Bollaert, S.; et al. DC characteristics of InAs/AlSb HEMTs at cryogenic temperatures. In Proceedings of the IEEE International Conference on Indium Phosphide \& Related Materials, Newport Beach, CA, USA, 10-14 May 2009; pp. 323-325.

3. Malmkvist, M.; Lefebvre, E.; Borg, M.; Desplanque, L.; Wallart, X.; Dambrine, G.; Bollaert, S.; Grahn, J. Electrical characterization and small-signal modeling of InAs/AlSb HEMTs for low-noise and high-frequency applications. IEEE Trans. Microw. Theory Tech. 2008, 56, 2685-2691. [CrossRef]

4. Moschetti, G.; Wadefalk, N.; Nilsson, P.A.; Abbasi, M.; Desplanque, L.; Wallart, X.; Grahn, J. Cryogenic InAs/AlSb HEMT wideband low-noise if amplifier for ultra-low-power applications. IEEE Microw. Wirel. Compon. Lett. 2012, 22, 144-146. [CrossRef]

5. Brennan, B.; Galatage, R.V.; Thomas, K.; Pelucchi, E.; Hurley, P.K.; Kim, J.; Hinkle, C.L.; Vogel, E.M.; Wallace, R.M. Chemical and electrical characterization of the HfO2/InAlAs interface. J. Appl. Phys. 2013, 114, 104103. [CrossRef] 
6. Guan, H.; Lv, H. Study on leakage current mechanism and band offset of high-k/n-InAlAs metal-oxide-semiconductor capacitors with $\mathrm{HfO}_{2}$ and $\mathrm{HfAlO}$ dielectric. Thin Solid Films 2018, 661, 137-142. [CrossRef]

7. Guan, H.; Lv, H.; Guo, H.; Zhang, Y.; Zhang, Y.; Wu, L. Interfacial and electrical characteristics of $\mathrm{HfO}_{2} / \mathrm{n}$-InAlAs MOS-capacitor with different dielectric thicknesses. Chin. Phys. B 2015, 24, 126701. [CrossRef]

8. Wu, L.; Zhang, Y.; Lu, H.; Zhang, Y. Interfacial and electrical characterization of $\mathrm{HfO}_{2} / \mathrm{Al}_{2} \mathrm{O}_{3} /$ InAlAs structures. Jpn. J. Appl. Phys. 2015, 54, 110303. [CrossRef]

9. Jin, C.; Lu, H.; Zhang, Y.; Zhang, Y.; Guan, H.; Wu, L.; Lu, B.; Liu, C. Transport mechanisms of leakage current in $\mathrm{Al}_{2} \mathrm{O}_{3}$ /InAlAs MOS capacitors. Solid State Electron. 2016, 123, 106-110. [CrossRef]

10. Huang, M.; Chang, Y.; Chang, Y.; Lin, T.; Kwo, J.; Hong, M. Energy-band parameters of atomic layer deposited $\mathrm{Al}_{2} \mathrm{O}_{3}$ and $\mathrm{HfO}_{2}$ on $\mathrm{In}_{x} \mathrm{Ga}_{1-x}$ As. Appl. Phys. Lett. 2009, 94, 2297. [CrossRef]

11. Dalapati, G.K.; Tong, Y.; Loh, W.Y.; Mun, H.K.; Cho, B.J. Electrical and interfacial characterization of atomic layer deposited high-k gate dielectrics on GaAs for advanced CMOS devices. IEEE Trans. Electron Devices 2007, 54, 1831-1837. [CrossRef]

12. Goel, N.; Majhi, P.; Chui, C.O.; Tsai, W.; Choi, D.; Harris, J.S. InGaAs metal-oxide-semiconductor capacitors with $\mathrm{HfO}_{2}$ gate dielectric grown by atomic-layer deposition. Appl. Phys. Lett. 2006, 89, 163517. [CrossRef]

13. Lin, T.D.; Chang, Y.H.; Lin, C.A.; Huang, M.L.; Lee, W.C.; Kwo, J.; Hong, M. Realization of high-quality $\mathrm{HfO}_{2}$ on $\mathrm{In}_{0.53} \mathrm{Ga}_{0.47}$ As by in-situ atomic-layer-deposition. Appl. Phys. Lett. 2012, 100, 172110.

14. Trinh, H.; Lin, Y.; Wang, H.; Chang, C.; Kakushima, K.; Iwai, H.; Kawanago, T.; Lin, Y.; Chen, C.; Wong, Y.; et al. Effect of postdeposition annealing temperatures on electrical characteristics of molecular-beam-deposited $\mathrm{HfO}_{2}$ on n-InAs/InGaAs metal-oxide-semiconductor capacitors. Appl. Phys. Express 2012, 5, 021104. [CrossRef]

15. Lin, Y.; Trinh, H.D.; Chuang, T.; Iwai, H.; Kakushima, K.; Ahmet, P.; Lin, C.; Díaz, C.H.; Chang, H.; Jang, S.M.; et al. Electrical characterization and materials stability analysis of $\mathrm{la}_{2} \mathrm{O}_{3} / \mathrm{HfO}_{2}$ composite oxides on $\mathrm{n}-\mathrm{In}_{0.53} \mathrm{Ga}_{0.47} \mathrm{As}$ MOS capacitors with different annealing temperatures. IEEE Electron Device Lett. 2013, 34, 1229-1231. [CrossRef]

16. Altuntas, H.; Donmez, I.; Ozgit-Akgun, C.; Biyikli, N. Effect of postdeposition annealing on the electrical properties of $\beta-\mathrm{Ga}_{2} \mathrm{O}_{3}$ thin films grown on $\mathrm{p}-\mathrm{Si}$ by plasma-enhanced atomic layer deposition. J. Vac. Sci. Technol. A 2014, 32, 041504. [CrossRef]

17. Liu, C.; Zhang, Y.; Zhang, Y.; Lv, H. Effect of atomic layer deposition growth temperature on the interfacial characteristics of $\mathrm{HfO}_{2}$ /p-GaAs metal-oxide-semiconductor capacitors. J. Appl. Phys. 2014, 116, 222207. [CrossRef]

18. Liu, C.; Zhang, Y.; Zhang, Y.; Lv, H. Interfacial characteristics of $\mathrm{Al} / \mathrm{Al}_{2} \mathrm{O}_{3} / \mathrm{ZnO} / \mathrm{n}-\mathrm{GaAs} \mathrm{MOS}$ capacitor. Chin. Phys. B 2013, 22, 406-409. [CrossRef]

19. Chang-Liao, K.S.; Lu, C.Y.; Cheng, C.L.; Wang, T.K. Process techniques and electrical characterization for high-k $\left(\mathrm{HfO}_{x} / \mathrm{N}_{y}\right)$ gate dielectric in MOS devices. In Proceedings of the 7 th International Conference on Solid-State and Integrated Circuits Technology, Beijing, China, 18-21 October 2004; pp. 372-377.

20. Cheong, K.Y.; Moon, J.H.; Kim, H.J.; Bahng, W.; Kim, N.K. Current conduction mechanisms in atomic-layer-deposited $\mathrm{HfO}_{2} /$ nitrided $\mathrm{SiO}_{2}$ stacked gate on $4 \mathrm{H}$ silicon carbide. J. Appl. Phys. 2008, 103, 084113. [CrossRef]

21. Quah, H.J.; Cheong, K.Y. Current conduction mechanisms of RF-Magnetron sputtered $\mathrm{Y}_{2} \mathrm{O}_{3}$ gate oxide on gallium nitride. Curr. Appl. Phys. 2013, 13, 1433-1439. [CrossRef]

(C) 2018 by the authors. Licensee MDPI, Basel, Switzerland. This article is an open access article distributed under the terms and conditions of the Creative Commons Attribution (CC BY) license (http://creativecommons.org/licenses/by/4.0/). 